\title{
Presepsin Levels in Emergency Patients with Bacterial and Viral Infection
}

\author{
Korakot Apiratwarakul ${ }^{1}$, Nipa Srimookda ${ }^{2}$, Pariwat Phungoen ${ }^{1 *}$, Kamonwon lenghong $^{1}$, Somsak Tiamkao ${ }^{1}$, \\ Vajarabhongsa Bhudhisawasdi ${ }^{1}$ \\ ${ }^{1}$ Department of Emergency Medicine, Faculty of Medicine, Khon Kaen University, Khon Kaen, Thailand; ${ }^{2}$ Accidental and \\ Emergency Unit, Division of Nursing, Srinagarind Hospital, Faculty of Medicine, Khon Kaen University, Khon Kaen, Thailand
}

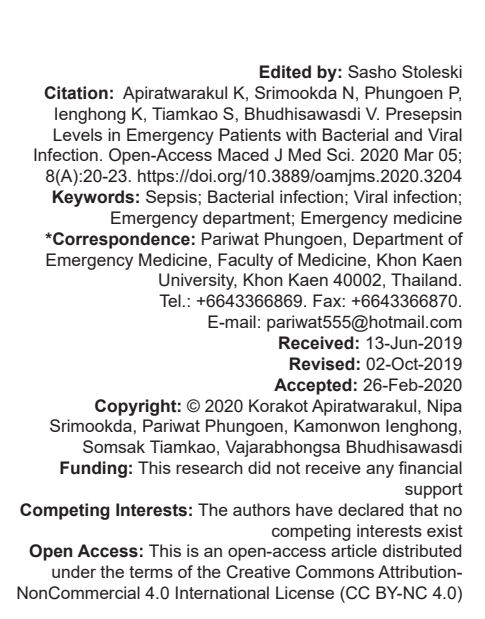

\section{Abstract}

BACKGROUND: Sepsis is a major problem with a high mortality rate, and emergency rooms are the first service point at which sepsis patients are treated. Blood presepsin levels are used as a tool to identify patients who may suffer from sepsis caused by bacterial infection, necessitating immediate antibiotic treatment.

AIM: The aim of the study was to evaluate presepsin levels in patients with bacterial and viral infections in the emergency department.

METHODS: This was a prospective study consisting of 88 patients over 18 years of age who visited the Srinagarind Hospital emergency room and fulfilled one or more criteria for systemic inflammatory response syndrome. Presepsin levels in the leftover blood specimens were tested.

RESULTS: In the bacterial infection group, $63.6 \%$ of the patients were male, and the mean age was $43.7 \pm$ 10.5 years. Mean presepsin levels were $2904.73, \mathrm{pg} / \mathrm{ml}$ in the bacterial infection group and $204.88 \mathrm{pg} / \mathrm{ml}$ in the vira infection group.

CONCLUSION: Presepsin levels in the bacterial infection group were significantly higher than in the viral infection group, in which they were below the standard cutoff point.

\section{Introduction}

Sepsis is a major problem with a high mortality rate. Diagnosis relies on history-taking, physical examination, and laboratory testing. There are more than 19 million patients per year diagnosed with sepsis worldwide. In the United States, there are more than 750,000 patients found per year, or 300 cases per hundred thousand people [1]. Up to $10 \%$ of cases of sepsis are critical, and it is the leading cause of death in critical care units in the Thailand (20-30\%). The disease has a mortality rate as high as $52.6 \%$ [2].

Emergency rooms are the first service point at which sepsis patients are treated. In the United States, there are over 260,000 cases per year that presents at emergency rooms (123 cases/100,000 population) [3]. Although rapid diagnosis and treatment are needed to reduce the mortality rate, the most laboratory tests currently being employed lack effective tools to diagnose this condition. It takes a long time to receive blood culture results, and the positive culture rates are low [4], [5], [6].
Presepsin (sCD14-ST) is a protein substance that is part of the truncated N-terminus of CD14, which enters the bloodstream when bacteria are eradicated through monocytes, macrophages, and neutrophils [7]. Therefore, presepsin values in the blood can be used as a tool to identify patients who may suffer from sepsis from bacterial infection [8], [9], [10], [11] and, thus, require immediate antibiotic treatment. There have yet been no studies on presepsin conducted in the Thailand, but studies from other regions have determined that the reference values in cases of suspected bacterial infection should be $>600 \mathrm{pg} / \mathrm{ml}$.

\section{Methods}

This was a prospective study. The sample consisted of 88 patients over 18 years of age who visited the Srinagarind Hospital emergency room between February 2019 and April 2019 and fulfilled one or more of the following diagnosis criteria for systemic 
inflammatory response syndrome: (1) Temperature $>38$ or $<36^{\circ} \mathrm{C}$, (2) heart rate $>90 / \mathrm{min}$, (3) respiratory rate $>20 / \mathrm{min}$ or $\mathrm{PaCO}_{2}<32 \mathrm{mmHg}$, and (4) white blood cell count $>12,000$ or $<4000 / \mathrm{mm}^{3}$ or immature granulocytes $\geq 10 \%$. The exclusion criteria were autoimmune disease and undergoing immunosuppressive therapy for tumors. Ethics approval was provided by the Khon Kaen University Ethics Committee for Human Research (HE621107).

The sample size was calculated based on the mean and standard deviation of presepsin levels reported in a previous study by Endo et al. [12]. To achieve a confidence interval of 0.95 and a power of test of 0.8 , we determined that a sample size of 88 would be required. Statistical analysis was performed using SPSS for Windows version 16.0 (SPSS Inc., Chicago, IL, USA). Categorical data were presented as percentages, and continuous data were presented using mean and standard deviation. Univariate analysis was performed using a two-sample t-test for numerical data and a Chi-squared test or Fisher's exact test for data comparison between the two groups.

The patients were classified into two groups: (1) The bacterial infection group, consisting of patients who were diagnosed with bacterial infection by a physician and had culture-positive samples (e.g., blood, sputum, urine, and abdominal fluids) and (2) the viral infection group, consisting of patients diagnosed with viral infection by a physician and tested positive on an influenza rapid test or for the dengue NS1 antigen. The presepsin level was measure by PATHFAST ${ }^{\circledR}$ point of care kits.

\section{Results}

Eighty-eight subjects were examined, the characteristics of whom are shown in Table 1. In the bacterial infection group, a total of $63.6 \%(n=14)$ of patients were male. The mean age was $43.7 \pm$ 10.5 years. Heart rate was $119.9 / \mathrm{min}$, respiratory rate $28.9 / \mathrm{min}$, temperature $39.1^{\circ} \mathrm{C}$, and white blood cell count $14.200 / \mathrm{mm}^{3}$. The duration to the onset of fever was 3.6 days in both groups.

Table 1: Characteristics of the subjects

\begin{tabular}{lll}
\hline Characteristics & $\begin{array}{l}\text { Bacterial infection } \\
(\mathrm{n}=22), \mathrm{n}(\%)\end{array}$ & $\begin{array}{l}\text { Viral infection } \\
(\mathrm{n}=66), \mathrm{n}(\%)\end{array}$ \\
\hline Sex: Male & $14(63.6)$ & $38(57.6)$ \\
Age \pm SD (years) & $43.7 \pm 10.5$ & $46.2 \pm 9.6$ \\
Onset of fever (days) & 3.6 & 3.6 \\
Heart rate $(/ \mathrm{min})$ & 119.9 & 120.5 \\
Respiratory rate $(/ \mathrm{min})$ & 28.9 & 26.5 \\
Temperature $\left({ }^{\circ} \mathrm{C}\right)$ & 39.1 & 39.3 \\
White blood cell count $\left(/ \mathrm{mm}^{3}\right)$ & 14.200 & 6542 \\
\hline
\end{tabular}

In the bacterial infection group, $31.8 \%$ of patients had positive sputum cultures and another $31.8 \%$ had positive blood cultures. Infections were caused by Gram-positive bacteria in $36.4 \%$ of cases, Gram-negative infection in or $31.8 \%$ of cases, and mixed Gram-positive and Gram-negative bacteria in $31.8 \%$ of cases, as shown in Table 2.

Table 2: Source of bacterial infection $(n=22)$

\begin{tabular}{lc}
\hline Source of infection & $\mathrm{n}(\%)$ \\
\hline Specimens & $7(31.8)$ \\
Sputum & $7(31.8)$ \\
Blood culture & $4(18.2)$ \\
Abdominal fluids & $2(9.1)$ \\
Urine & $2(9.1)$ \\
Cerebrospinal fluids & \\
Type of infection & $8(36.4)$ \\
Gram-positive infection & $7(31.8)$ \\
Gram-negative infection & $7(31.8)$ \\
Mixed Gram-positive and Gram-negative infection & \\
\hline
\end{tabular}

The cause of infection in the viral group was influenza in $65.2 \%$ of cases and dengue in $34.8 \%$ (Table 3).

Table 3: Source of viral infection $(n=66)$

\begin{tabular}{ll}
\hline Source of infection & $\mathrm{n}(\%)$ \\
\hline Influenza rapid test & $43(65.2)$ \\
Dengue NS1 antigen & $23(34.8)$ \\
\hline
\end{tabular}

The mean of presepsin level in bacterial group was $2904.73 \mathrm{pg} / \mathrm{ml}$ and that in the viral group was $204.88 \mathrm{pg} / \mathrm{ml}$, as shown in Table 4 and Figure 1.

Table 4: Presepsin level

\begin{tabular}{llll}
\hline Presepsin level & Mean $(\mathrm{pg} / \mathrm{ml})$ & Standard deviation & $95 \% \mathrm{Cl}$ \\
\hline Bacterial infection $(\mathrm{n}=22)$ & 2904 & 3540 & $1334-4474$ \\
Viral infection $(\mathrm{n}=66)$ & 204 & 165 & $164-245$ \\
\hline
\end{tabular}

The presepsin level mostly in patients with blood culture positive $2261 \mathrm{pg} / \mathrm{ml}$ and cerebrospinal fluids culture positive $2244 \mathrm{pg} / \mathrm{ml}$ with significantly associated with patients culture negative $(p<0.001$; Table 5$)$.

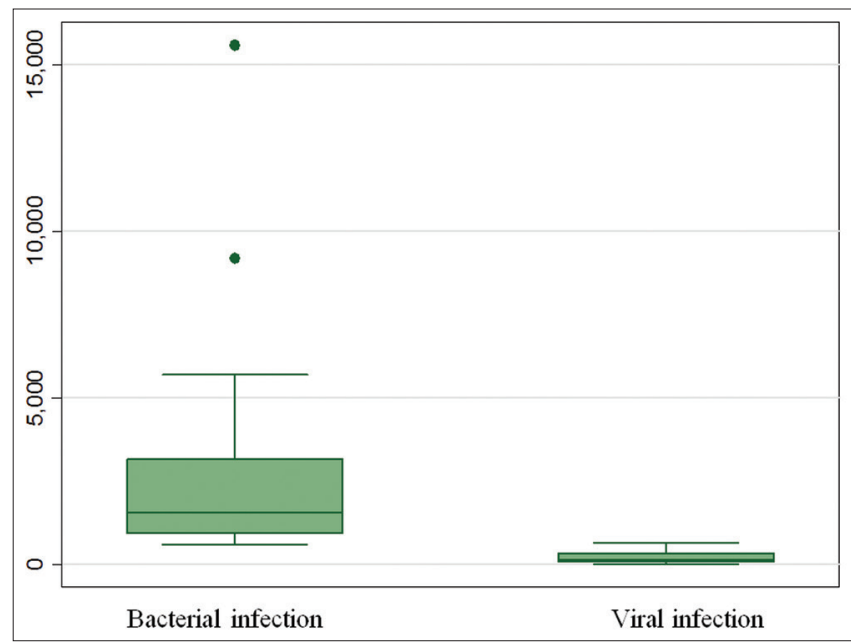

Figure 1: Presepsin level (pg/ml)

\section{Discussion}

Presepsin, found in 2004, is a highly specific biomarker for bacterial infection and sepsis because it 
Table 5: Presepsin level with factors

\begin{tabular}{lllll}
\hline Culture groups & \multicolumn{3}{l}{ Presepsin level $(\mathrm{pg} / \mathrm{ml})$} & p-value \\
\cline { 2 - 4 } & Mean & $25^{\text {th }}$ percentile & $75^{\text {th }}$ percentile & \\
\hline Culture negative, negative & 154 & 74 & 327 & $<0.001$ \\
Gram's stain & & & & \\
Culture positive & 1551 & 681 & 4057 & \\
$\quad$ Sputum & 949 & 740 & 1609 & $<0.001$ \\
$\quad$ Abdominal fluids & 1264 & 940 & 1588 & \\
$\quad$ Urine & 2244 & 1336 & 3152 & \\
$\quad$ Cerebrospinal fluids & 2261 & 1125 & 5687 & \\
$\quad$ Blood culture & & & & \\
Positive organism & 1979 & 1378 & 3874 & \\
$\quad$ Gram-positive infection & 1125 & 689 & 2261 & \\
$\quad$ Gram-negative infection & 1336 & 653 & 4057 & \\
$\quad$ Mixed Gram-positive & 135 & & \\
$\quad$ Gram-negative infection & & & &
\end{tabular}

is produced by bacterial phagocytosis [13]. This study was found that presepsin levels in the bacterial infection group were significantly higher than in the viral infection group, which is consistent with the results of the previous studies [7], [8], [9], [10], [11], [12], [13], [14]. The previous studies have found presepsin level cutoff points of $>600 \mathrm{pg} / \mathrm{ml}$ [12], $>407 \mathrm{pg} / \mathrm{ml}$ [7], and $>413 \mathrm{pg} / \mathrm{ml}$ [14] in patients with bacterial infection. These studies also found presepsin levels below the standard cutoff points in patients with viral infection [7], [12], [14] (both influenza and dengue).

A study by Lu et al. [7] found that presepsin levels were associated with both Gram-positive and Gram-negative infection, which is similar to the results of this study, with the exception that there was no significant difference in presepsin levels between Gram-positive and Gram-negative bacterial infections.

This study showed that presepsin levels were useful for diagnosis of sepsis in patients with bacterial infection, as they were higher than the standard cutoff point. This was the case in both blood culturepositive patients and patients with other culture-positive specimens, which is similar to the results found by Endo et al. [12]. However, this study was limited in that it had a small sample size and did not test in patients with other types of infection (such as fungal infection).

\section{Conclusion}

Presepsin levels in the bacterial infection group were significantly higher than in the viral infection group, which were below the standard cutoff point. Presepsin can be used as a rapid detection tool for the diagnosis of bacterial infection in emergency patients.

\section{Acknowledgments}

The authors would like to thank Kaewjai Thepsuthammarat for her data analysis and statistical review and Dylan Southard for acting as English consultant.

\section{References}

1. Angus DC, Van der Poll T. Severe sepsis and septic shock. N Engl J Med. 2013;369(9):840-51. https://doi. org/10.1056/nejmra1208623

PMid:23984731

2. Angkasekwinai N, Rattanaumpawan $P$, Thamlikitkul V. Epidemiology of sepsis in Siriraj Hospital 2007. J Med Assoc Thai. 2009;92(Suppl 2):S68-78.

PMid:19562989

3. Filbin MR, Arias SA, Camargo CA, Barche A, Pallin DJ. Sepsis visits and antibiotic utilization in U.S. emergency departments. Crit Care Med. 2014;42(3):528-35. https://doi.org/10.1097/ ccm. 0000000000000037

PMid:24201179

4. Kibe S, Adams K, Barlow G. Diagnostic and prognostic biomarkers of sepsis in critical care. J Antimicrob Chemother. 2011;66(Suppl 2):33-40.

PMid:21398306

5. Wacker C, Prkno A, Brunkhorst FM, Schlattmann P. Procalcitonin as a diagnostic marker for sepsis: A systematic review and meta-analysis. Lancet Infect Dis. 2013;13(5):426-35. https://doi. org/10.1016/s1473-3099(12)70323-7

PMid: 23375419

6. Sridharan P, Chamberlain RS. The efficacy of procalcitonin as a biomarker in the management of sepsis: Slaying dragons or tilting at windmills? Surg Infect. 2013;14(6):489-511. https://doi. org/10.1089/sur.2012.028

PMid: 24274059

7. Lu B, Zhang Y, Li C, Liu C, Yao Y, Su M, et al. The utility of presepsin in diagnosis and risk stratification for the emergency patients with sepsis. Am J Emerg Med. 2018;36(8):1341-5. https://doi.org/10.1016/j.ajem.2017.12.038 PMid: 29276032

8. Shirakawa K, Naitou K, Hirose J, Takahashi T, Furusako S. Presepsin (sCD14-ST): Development and evaluation of one-step ELISA with a new standard that is similar to the form of presepsin in septic patients. Clin Chem Lab Med. 2011;49(5):937-9. https://doi.org/10.1515/cclm.2011.145 PMid: 21345045

9. Shozushima T, Takahashi $\mathrm{G}$, Matsumoto $\mathrm{N}$, Kojika $\mathrm{M}$ Okamura $Y$, Endo S. Usefulness of presepsin (sCD14-ST) measurements as a marker for the diagnosis and severity of sepsis that satisfied diagnostic criteria of systemic inflammatory response syndrome. J Infect Chemother. 2011;17(6):764-9. https://doi.org/10.1007/s10156-011-0254-x PMid: 21560033

10. Okamura Y, Yokoi H. Development of a point-of-care assay system for measurement of presepsin (sCD14-ST). Clin Chim Acta. 2011;412(23-24):2157-61. https://doi.org/10.1016/j. cca.2011.07.024

PMid: 21839732

11. Sugie $\mathrm{Y}$, Igami $\mathrm{K}$, Shoji $\mathrm{K}$, Arai $\mathrm{N}$, Tazaki $\mathrm{Y}, \mathrm{Kouta} \mathrm{H}$, et al Performance evaluation of the new rapid fertility assays in whole blood and plasma on PATHFAST. Clin Lab. 2011;57(1-2):99-106. PMid:21391473

12. Endo S, Suzuki $Y$, Takahashi G, Shozushima T, Ishikura $H$, 
Murai $\mathrm{A}$, et al. Usefulness of presepsin in the diagnosis of sepsis in a multicenter prospective study. J Infect Chemother. 2012;18:891-7. https://doi.org/10.1007/s10156-012-0435-2

PMid: 21391473

13. Yaegashi $\mathrm{Y}$, Shirakawa K, Sato N, Suzuki Y, Kojika M, Imai S, et al. Evaluation of anewly identified soluble CD14 subtype as a marker for sepsis. J Infect Chemother. 2005;11(5):234-8. https:// doi.org/10.1007/s10156-005-0400-4

PMid: 16258819

14. Godnic M, Stubljar D, Skvarc M, Jukic T. Diagnostic and prognostic value of SCD14- ST-presepsin for patients admitted to hospital intensive care unit (ICU). Wien Klin Wochenschr. 2015;127(1314):521-7. https://doi.org/10.1007/s00508-015-0793-8 PMid: 25854904 